\title{
Halal Virtual Inspection Critical Control Point
}

\author{
Mohd Zabiedy Mohd Sulaiman, Nurulhuda Noordin, Nor Laila Md Noor, Ahmad Iqbal Hakim Suhaimi, Wan \\ Abdul Rahim Wan Mohd Isa \\ Dept Computer and Mathematical Sciences, Universiti Teknologi MARA, Selangor, Malaysia \\ zabiedy.s@outlook.com \\ Dept Computer and Mathematical Sciences, Universiti Teknologi MARA, Selangor, Malaysia \\ hudanoordin@tmsk.uitm.edu.my \\ Dept Computer and Mathematical Sciences, Universiti Teknologi MARA, Selangor, Malaysia \\ norlaila@tmsk.uitm.edu.my \\ Dept Computer and Mathematical Sciences, Universiti Teknologi MARA, Selangor, Malaysia \\ aiqbal@tmsk.uitm.edu.my \\ Dept Computer and Mathematical Sciences, Universiti Teknologi MARA, Selangor, Malaysia \\ wrahim2@tmsk.uitm.edu.my
}

\begin{abstract}
The critical control points (CCP) are a vital component in product safety and control measures where the precautionary operation can be applied to reduce hazards in production. In halal certification (HC), it is significant to identify the CCP in order to confirm any products or services are halal. As a form of quality assurance system, $\mathrm{HC}$ which consists of several control measures used to emphasize the CCP from the Islamic point-of-view. However, it is a complex system and there are issues that require some action of improvement. If not handled properly, the key HC process such as Halal Inspection (HI) can lead to the operational inefficiency of the system. Therefore, the existing inspection method needs to adapt to the current situation and its operation must be improved. This article attempts to highlight the CCP of HI by focusing on the inspection process for small and medium-sized food premises conducted in Malaysia. This exploratory research is carried out qualitatively through several interviews with experts in HC field and observations on $\mathrm{HI}$ process at 10 food premises. The Work System Framework (WSF) and Computer Supported Cooperative Work (CSCW) framework are used as the basis for this research. The outcomes uncovered numerous requirements for the $\mathrm{HI}$ process which will be a vital component that can be used to empower the existing HC system. In this context, the benefit of modern technological advancement such as virtual technology can effectively be utilized to expand the effectiveness of the HC system, mainly in the HI process.
\end{abstract}

Keywords— Halal inspection, critical control points, halal certification, virtual technology, HACCP.

\section{INTRODUCTION}

Inspection is a process conducted by individual or organizations to ensure the related guidelines and requirements are fulfilled [1]. Commonly, an inspection often describes in various ways due to the broad nature of the definition of 'inspection'. The word inspection comes from a Latin word inspectionem which means an act of careful and critical examination [2] used for many purposes including aircraft maintenance, baggage screening, food industry, medical sectors and nuclearrelated sectors such as such as pharmaceutical, radiology and nuclear energy and weaponry respectively. This process plays a significant role in many areas to ensure the production results reach the expected safety standard. Throughout the inspection process, the inspector will be able to examine the relevant Critical Control Point (CCP).
An inspection helps to identify any hazards in production as food products can be risky in term of a medium for disease transmission. If the control measure is not implemented, it can lead to illness or even death [3]. For example, in Malaysia food industry, illness cases related to food often triggered by several factors and mostly by microbiological hazards such as improper training of food handling, the use of untreated water for non-drinking purposes (i.e. in food preparation, cooking, washing, etc.) as well as lack of enforcement or maintenance of sanitation and hygiene operation [4]. Besides, "other than ready-to-eat foods and water sources, food handlers themselves are also a source for the contamination" [4]. This can lead to many diseases' outbreaks. Therefore, everything needs to be verified through a proper inspection process from the documentation, safety measures, handling practices, food ingredients until the raw materials. Due to that, there are many food safety standards or quality 
assurance systems (QAS) were introduced and used for various purposes especially in food production sectors. This includes common QAS such as the Good Manufacturing Practices (GMP), Good Hygiene Practices (GHP), Hazard Analysis Critical Control Points (HACCP), Codex Alimentarius and many more [5].

In the Islamic point-of-view, an inspection brings broader definitions which associated with the HalalanThoyyiba concept. This concept is a combination of two Arabic words which is halal and thoyyib. Halal derived from halla, yahillu, hillan and waHalalan which means anything that legal for the Muslims consumption according to the Shariah (Islamic law) while thoyyib represents something that nutritious, clean, quality and safe [3], [6]. As stated in the Trade Descriptions (Definition of Halal) Order 2011 and Trade Descriptions (Definition of Halal) (Amendment) Order 2012, anything that is pure halal must be free from any animal parts that prohibited in Islam. Besides, it is also must not be hazardous and/or prepared using the instrument that contaminated with haram products (haram means the opposite of halal which refer to anything that prohibited in Islam) [5], [6].

Islam is a way of life for Muslims and consuming only halal products is their religious obligation. In the context of food consumption, Muslims are guided by the Islamic dietary law, which at the beginning of Islam, it is the only regulation for safe, wholesome and Muslim-friendly products [7]. As time changes, the complexity and advancement of current technology in the food industry show the need for a better way to preserve halal. Therefore, a proper halal assurance system and efficient inspection method are needed which leads to the introduction of Halal Certification system. Halal certification plays an enormous role in the Islamic world because its evaluation process covers everything from technical to religious aspects. Halal certification system has the same requirement as other existing QAS (i.e. GMP, GHP and HACCP) as it provides a way to ensure the safety, health level as well as the quality of the products which makes it essential for the certification system [8]. It consists of several main processes starting from the application stage until the issuance of the halal certificate or logo, which is a document that used to show the halal status. Among all the processes in the system, the halal inspection process is the most important part and will determine the success of the halal certification application [1].

There is no doubt that the existing QAS has its advantages and contribution where the inspection process more on evaluating the technical aspects. However, Muslims cannot just rely on the existing QAS alone. In this respect, halal certification provides a more comprehensive verification approach for the Muslim community due to the religious values that implemented in the system which acts as 'pillar' of its evaluation process. There are many studies have been conducted regarding the issues in the halal certification system[8] [10]. Amongst them, the operational inefficiency requires some action of improvement as halal certification can be time-consuming process and high cost mainly in term of the travel expenses for the inspection process [11], [12]. The researcher believes that halal certification needs to evolve and implement better technology in the system. Operating each process of the system through a better approach rather than adding more inspections can be a great solution [13].

This research aims to explore the best approach for the use of information and communication technology (ICT) such as virtual technology to improve the existing certification method. As the initial step to this noble work, the halal inspection process critical control points (CCP) need to be highlighted. This article focuses on the halal certification system and halal inspection process conducted by the Halal Certification Body in Malaysia. The Work System Framework (WSF) [14] is adopted as the guideline to extract the relevant information on the research topics. The researcher believes that virtual technology can be utilized efficiently in the halal certification field as a platform for collaborative working team accomplishes their goals. In this context, the halal inspection process needs to be flexible; across time and space/place barrier. Thus, the Computer Supported Cooperative Work (CSCW) [15] framework which provides a structure for creating such a shared working environment in the $\mathrm{HC}$ field making it a suitable basis for this research. Although the use of technology is not something prohibited in Islam, every component of this approach must comply with the Islamic law. This article is organized into sections comprising of the introduction, literature review, methodology, analysis and results, discussions and the conclusions.

\section{LITERATURE REVIEW}

This section provides the review on topics related to this research.

\section{A. Quality Assurance System (QAS)}

Taking precaution actions to prevent any unwanted effects before, during and after production of goods or services is crucial in various sectors. In the food industry, for example, this includes the implementation of preproduction food hygiene practices, design, creation and maintenance of equipment and building structures, cleaning and sanitizing programmes, pest control, personal hygiene and employee training [16]. These are some of many critical food hygiene matters that require 
strict control through a Quality Assurance System (QAS). QAS is a systematic prerequisite system that evaluates every component in the food production through a documented verification procedure [17]. It involves the assessment of one or many criteria of the product or goods by comparing it with the relevant requirements or evaluation expectations [18]. QAS can be viewed to prevent mistakes in production and helps to avoid any issue before delivering products to the end user or consumer. According to Rotaru [19], the most common prerequisites systems includes the Good Manufacturing Practices (GMP), Good Hygiene Practices (GHP) and Hazard Analysis Critical Control Points (HACCP). Sometimes, these QAS acts as a preventive tool to avoid or reduce the risk of contamination and often indicated as food safety or quality standards used in many areas.

The Good Manufacturing Practices (GMP) is considered the least hygienic and handling requirements for food establishments [19]. According to the Department of Standards Malaysia [20], GMP is a set of rules and guiding principles that allow the implementation of control measures for the food establishment produce a safe and quality food product. It is a 'good housekeeping' guideline in the food production sector for example, which helps to ensure the consistency of the product quality, reduced waste and consequently enhancing the profits [21]. The main purpose of GMP is more on the preventive actions that can be applied at the primary stage of production. This is to confirm that everything complies with the related quality and safety requirements. Another important QAS is Good Hygiene Practices (GHP). Ministry of Health Malaysia [22] described GHP as a situation, preventive actions and safety standards of buildings, facilities, equipment, workers, processing and handling procedure, storage, shipping and the environment that required for the quality food production and manufacturing. While GMP focused on the technical part in foods, products or goods manufacturing, GHP more on emphasizing the hygiene aspect during production [21]. Both GMP and GHP often used together as it provides the necessary outline of proper and hygienic production method. Additionally, Hazard Analysis Critical Control Points (HACCP) is another QAS that synonym with food safety and quality control. "It is a systematic approach to analyse food processing and identify any hazards presence of chemical, physical, or biological agents into foods" [23]. HACCP is used to cut the risk of potential hazards and provide the safety of the products in the whole food and supply chain, identify the risk points and establish a measure for their control at the stage of food production [16], [21].
GMP, GHP and HACCP have its own advantages despite its weaknesses. This one of the factors that makes it applied collectively to the enhanced safety and preventive action. But, in term of its application for the Muslim world, it still requires some additional criteria in its evaluation process that extend to not just the technical requirement but also on the halal concept and Islamic religious obligation. In other words, the mixture of the existing QAS and the Shariah (Islamic law) lead to the implementation of Halal Certification system making it helpful for the Muslim community.

\section{B. Halal Certification System}

Halal certification system provides evaluation and confirmation of products or services to ensure it complies with the halal requirement and the Shariah (Islamic law) [24], [25]. This is to detect and ensure whether the products are halal or not [7]. Besides, it also helps to protect the right of Muslims consumers in halal products consumption and to provide them with a form of guidance during product purchasing and decision making. Generally, halal certification can easily be identified in the form of Halal Certificate and Halal Logo to show the halal status. In the halal certification field, everything must be verified from both technical and Islamic perspectives. But the verification process may not always be the same all over the world as there are many Halal Certification Bodies worldwide. Different country may have different certification procedure depending on the demographical setting and local culture. On the other hand, it is also affected by "minor differences in the interpretation of certain aspects of the Shariah (Islamic laws) according to the different Islamic School of Thought or mazhab" which practised by Muslims in different countries [5]. This is because there is no unified and universal halal certification guideline or standard that can be applied by different countries all over the world. However, the basic structure of the halal certification system usually implemented in a similar way.

According to Noordin [26], there are five main processes of the halal certification system which starts with (i) the application by the applicant through the manual form or online application system. After the application received by the Halal Certification Body, the application will be processed and then, (ii) Halal Inspection process will be conducted. There two parts of halal inspection that will be carried out to ensure the inspection criteria are fulfilled which are the Off-site Inspection and On-site Inspection process [26], [27]. Next, the findings of the inspection process will be compiled by the Halal Auditor (food inspector) to be (iii) presented and assessed by the Halal Certification Panels. If approved, the Halal Certificate and Halal Logo will be (iv) issued to the applicant. Otherwise, the applicant will be 
informed regarding the rejection of their application for further action of improvement. Finally, ( $v$ ) the certified premises (halal certificate holder) will continuously be monitored by the Halal Certification Body to ensure that 'halal' is always be practice.

TABLE I TYPE OF HALAL INSPECTION

\begin{tabular}{|l|l|}
\hline \multicolumn{2}{|c|}{ Appearance (in Time New Roman or Times) } \\
\hline Type & Descriptions \\
Scheduled & $\begin{array}{l}\text { Carried out on the halal certificate } \\
\text { holders to verify its compliance with } \\
\text { certification requirements through a } \\
\text { continuous and planned inspection } \\
\text { process. }\end{array}$ \\
\hline $\begin{array}{l}\text { Enforcement } \\
\text { inspection }\end{array}$ & $\begin{array}{l}\text { Conducted by Halal Certification Body } \\
\text { with the support from other } \\
\text { enforcement agencies (i.e. Ministry of } \\
\text { Health, etc.) as a result of the public } \\
\text { complaint or from schedule inspection } \\
\text { activities. }\end{array}$ \\
\hline $\begin{array}{l}\text { Follow-up } \\
\text { inspection }\end{array}$ & $\begin{array}{l}\text { An inspection of any halal certificate } \\
\text { holders which failed to comply with } \\
\text { the halal certification procedures } \\
\text { based on the earlier inspections. }\end{array}$ \\
\hline $\begin{array}{l}\text { Inspection } \\
\text { based on } \\
\text { complaint }\end{array}$ & $\begin{array}{l}\text { Carried out after receiving a public } \\
\text { complaint pertaining halal-related } \\
\text { issues (i.e. the abuse of halal } \\
\text { logo/certificate, unclear halal status on } \\
\text { products and consumer goods, food } \\
\text { premises, logistics or companies, and } \\
\text { the use of the halal logo or halal term. }\end{array}$ \\
\hline
\end{tabular}

Taking the example of halal certification implementation in Malaysia where the monitoring and enforcement process is conducted similarly as the normal halal inspection process. The difference is that the halal certificate holder will not be given any early notice by the Halal Certification Body regarding the inspection. In Malaysia, there are four types of halal inspection as previously described (see Table I).

1) Current Scenario of Halal Inspection: Halal inspection allows the Halal Auditor to conduct a proper examination on all aspect in the production and collect 'evidence of non-compliance' as much as possible. In the context of food, this process includes everything from the raw materials, storage, processing plant, manufacturing flow and handling procedure, general hygiene, packaging materials, quality control, finished products and assurance practice [28]. Regular inspection involves the assessment of products or systems for the control of food, raw materials, processing and distribution in order to verify that it has met the required safety standard [5]. Like other inspection processes, halal inspection also covers the technical criteria such as evaluation on the raw materials used, processing, and many more. However, these criteria will be evaluated from the Islamic perspective as everything must comply with the halal requirements. It will also be verified in term of its sanitary, health level and the halal matters. In this study, the researcher focuses on the halal inspection process conducted at various types of food premises by the Halal Certification Body in Malaysia.

Halal inspection can be classified into two main components which are the Off-site Inspection and On-site Inspection process. As depicted in Fig.1, the Off-site Inspection which also known as desk-inspection is performed by the Halal Certification Body through reviewing and verifying the application form and supporting documents. This includes common requirements of the system such as the descriptions of the business and the applicant (i.e. company profile, product specification, etc.), the workers and many more. This process is carried out internally by the Halal Auditor; who are the experts in technical aspect (food technology) and Shariah (Islamic studies) [28]. The second part of the halal inspection process is the On-site Inspection. This is the stage where physical premise evaluation will be done by the Halal Auditor with the support from the several government departments and private organisations. They are using numerous guidelines including the Manual Procedure for Malaysia Halal Certification [6], Malaysia Halal Standards, the related food acts and regulations as well as the Halal Inspection Checklist during the process.

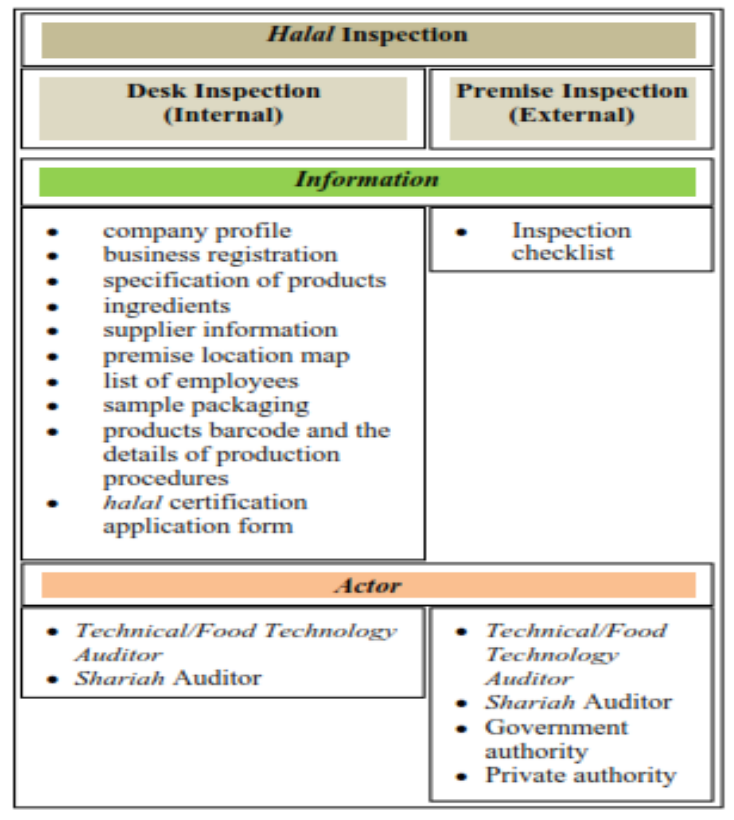

Fig.1 Halal Inspection Model [29]

C. Related Theory 
There are two main frameworks used as the basis for this research which is the Work System Framework (WSF) and the Computer Supported Cooperative Work (CSCW) which will further discuss in the following sections.

1) Work System Framework (WSF): "A system is about anything that involves electronic information processing" [14] and a 'work system' is where human as participants of a system using a technology to accomplish their working goals. This is done by using any accessible information and resources to produce a specific product and/or services to be delivered to a specific consumer. The Work System Framework (WSF) used to visualize a work system in the form pictorial representation of nine components (see Fig. 2) that outlines a work system's form, function and environment. These nine components of the framework gives a fundamental understanding of a work system and helps in painting a broader picture of a work system that includes human as participants, the output (product or services), information and technologies that used to produce the output, the end users (customers), the working environment, infrastructure, and also relevant strategies" [30]. It is considered as a proper basis for relating and evaluating a work system of information technology (IT)-reliant in the organization [14].

In the context of this research, the nine components of the WSF is suitable for this work as it is helpful to extract the information needed regarding the research topics. This study focusses on several aspects based on the element of the framework mainly on the processes and activities of the halal certification system and halal inspection process, the individuals or organisations involved (participants), the information used, and technology implemented by the participants in the work system. This is essential in order to identify the critical control points (CCP) of halal inspection process so that the component for halal inspection virtualization can be uncovered.

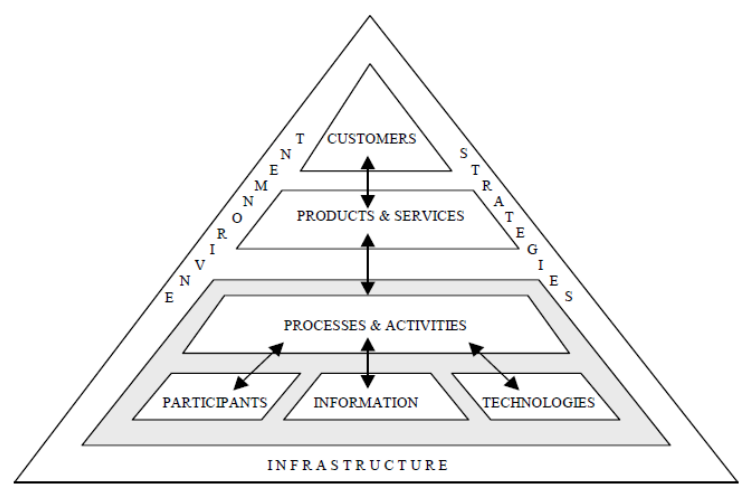

Fig. 2 Work System Framework [14]

2) Computer Supported Cooperative Work (CSCW): CSCW framework is applicable for the halal inspection virtualization as it gives basic support for the researcher on understanding how a human can interact and work cooperatively with the support of technology. This is because technology can assist human to accomplish their goals and CSCW shows a way on how it can affect humans collaborative work [31]. The term CSCW was first introduced by Irene Greif and Paul Cashment in 1984 which defined the framework as "a set of concerns about supporting multiple individuals working together with computer systems [32]. CSCW helps in creating an integrated working environment that enables the users, in this case; the participants and customers of the shared system (i.e. Halal Auditor) to collaborate, interact and work in more flexible approach across the boundaries of time and place or space [31]. The shared environment should allow interaction between participants where they can see each other (i.e. through video cameras), work and able to transmit audio for communication.

The interaction between human participants and technology can take place not only in the same physical space but also in distance [15]. This situation can occur synchronously or asynchronously. For example, meeting room, conference room, emails, short message service (SMS) and shared whiteboards. Both mode of interaction and communication helps in various ways as it has its own advantages which makes it significant to be implemented for this research. According to Mørch [32], synchronous communication occurred in real-time where the interaction is good support for awareness of others in the work system and relevant in a variety of situations and applications. Meanwhile, asynchronous communication occurred indirectly which enables the participants to make reflection before coming out with the next decision while relating (over time) with others. Despite its benefits, both interactions also bring some drawbacks which require special attention. In term of synchronous communication, there are situations where developing the technology for the interaction might be complex and require high individual concentration to be implemented. In the asynchronous interaction, it can affect the social interaction between the work system participants to the minimum [32].

The collaborative interaction in a work system can be classified into four groups. This often demonstrated in the CSCW framework through the Johansen's TimeSpace Matrix (see Fig. 3). In the halal certification system, the current halal inspection process is employed physically at the applicant's premises. This method can occur in face-to-face (F2F) and/or asynchronous interactions. In order to implement the inspection process virtually, halal inspection can be extended to the higher level; through synchronous or asynchronous distributed interaction. However, to ensure the success 
of this approach, all halal inspection requirements must be fulfilled, and the virtual method should not be compromised with the Islamic law.

\begin{tabular}{|c|c|c|}
\hline & Same time & Different time \\
\hline $\begin{array}{c}\text { Same } \\
\text { place }\end{array}$ & $\begin{array}{c}\text { Face-to-face } \\
\text { interaction }\end{array}$ & $\begin{array}{c}\text { Asynchronous } \\
\text { interaction }\end{array}$ \\
\hline $\begin{array}{c}\text { Different } \\
\text { place }\end{array}$ & $\begin{array}{c}\text { Synchronous } \\
\text { distributed } \\
\text { interaction }\end{array}$ & $\begin{array}{c}\text { Asynchronous } \\
\text { distributed } \\
\text { interaction }\end{array}$ \\
\hline
\end{tabular}

Fig. 3 Johansen's Time-Space Matrix [15]

\section{Methodology}

This section discusses the methods used in this research.

\section{A. Interview}

Three semi-structured interviews with five experts in halal certification field in Malaysia were carried out separately to obtain the information needed for this research. Several open-ended interview questions were constructed and used during the one-hour session to guide the researcher in the data collection process. The questions highlight the important topics (i.e. the processes and activities, the participants, and the technology used). Each session was voice recorded with the respondents' permission which then, the collected data is transcribed and analysed.

TABLE II DESCRIPTIONS OF INTERVIEW RESPONDENTS

\begin{tabular}{|c|c|}
\hline Respondents & Descriptions \\
\hline \multicolumn{2}{|c|}{ Interview 1 (Shariah Halal Auditors) } \\
\hline $\begin{array}{l}\text { Halal } \\
\text { Auditor } 1\end{array}$ & $\begin{array}{l}\text { - Assistant Director. } \\
\text { - } 4 \text { years of service in halal certification field. } \\
\text { - Bachelor of Islamic Studies (Hons.) } \\
\text { (Shariah) }\end{array}$ \\
\hline $\begin{array}{l}\text { Halal } \\
\text { Auditor } 2\end{array}$ & $\begin{array}{l}\text { - Assistant Director. } \\
\text { - A few years of service in halal certification. } \\
\text { - Bachelor of Usuluddin }\end{array}$ \\
\hline \multicolumn{2}{|c|}{ Interview $\mathbf{2}$ (Technical Halal Auditors) } \\
\hline $\begin{array}{l}\text { Halal } \\
\text { Auditor } 3\end{array}$ & $\begin{array}{l}\text { - Assistant Director. } \\
\text { - Involved in halal certification field since } \\
\text { 2009. } \\
\text { - Bachelor of Food Science and Technology }\end{array}$ \\
\hline $\begin{array}{l}\text { Halal } \\
\text { Auditor } 4\end{array}$ & $\begin{array}{l}\text { - Assistant Director. } \\
\text { - Involved in halal certification field since } \\
2011 . \\
\text { - BSc. (Hons.) (Chemical Sciences and Food } \\
\text { Technology); Diploma in Laboratory } \\
\text { Technology }\end{array}$ \\
\hline
\end{tabular}

\begin{tabular}{|l|l|}
\hline Halal & - Assistant Director (since 2014). \\
Auditor 5 & $\begin{array}{l}\text { - Appointed as Halal Auditor since 2012. } \\
\text { - Bachelor of Shariah }\end{array}$ \\
\hline
\end{tabular}

\section{B. Observations}

Ten food premises of various types were selected, inspected and observed to determine the difference between each inspection in a different location. It consists of four chain restaurants, one hotel kitchen, four food kiosks and one franchise restaurant. Table III summarises the observations.

TABLE III DESCRIPTIONS OF OBSERVATIONS

\begin{tabular}{|c|c|c|}
\hline Premises & Duration & Descriptions \\
\hline \multicolumn{3}{|c|}{ First Day: Kuala Lumpur } \\
\hline $\begin{array}{l}\text { Premise } 1 \\
\text { (chain } \\
\text { restaurant) }\end{array}$ & $\begin{array}{l}1 \text { hour, } \\
5 \text { minutes }\end{array}$ & $\begin{array}{l}\text { - Halal certification: new } \\
\text { application. } \\
\text { - Inspection area: kitchen, } \\
\text { food preparation, raw } \\
\text { materials storage. }\end{array}$ \\
\hline \multicolumn{3}{|c|}{ Second Day: Shah Alam, Selangor } \\
\hline $\begin{array}{l}\text { Premise } 2 \\
\text { (hotel } \\
\text { kitchen/ } \\
\text { restaurant) }\end{array}$ & $\begin{array}{l}1 \text { hour, } \\
40 \text { minutes }\end{array}$ & $\begin{array}{l}\text { - Halal certification: renewal } \\
\text { application. } \\
\text { - Inspection area: main } \\
\text { kitchen; Chinese, pastry } \\
\text { and butcher kitchen, food } \\
\text { preparation, storage, } \\
\text { waste disposal, workers' } \\
\text { hygiene and operating } \\
\text { practices. }\end{array}$ \\
\hline $\begin{array}{l}\text { Premise } 3 \\
\text { (chain } \\
\text { restaurant) }\end{array}$ & 30 minutes & $\begin{array}{l}\text { - Halal certification: new } \\
\text { application. } \\
\text { - Inspection area: dining and } \\
\text { serving, food handling, } \\
\text { preparation, racks, storage. }\end{array}$ \\
\hline \multicolumn{3}{|c|}{ Third Day: Subang Jaya, Selangor } \\
\hline $\begin{array}{l}\text { Premise } 4 \\
\text { (food kiosk) }\end{array}$ & 45 minutes & $\begin{array}{l}\text { - Halal certification: new } \\
\text { application. } \\
\text { - Inspection area: food } \\
\text { handling, mini kitchen } \\
\text { (with storage - racks, \& } \\
\text { cabinets only) and dining. }\end{array}$ \\
\hline $\begin{array}{l}\text { Premise } 5 \\
\text { (food kiosk) }\end{array}$ & 18 minutes & $\begin{array}{l}\text { - Halal certification: new } \\
\text { application. } \\
\text { - Inspection area: food } \\
\text { handling, mini kitchen, } \\
\text { dining area, storage, racks, } \\
\text { cabinets. }\end{array}$ \\
\hline $\begin{array}{l}\text { Premise } 6 \\
\text { (franchise } \\
\text { restaurant) }\end{array}$ & $\begin{array}{l}1 \text { hour, } \\
20 \text { minutes }\end{array}$ & $\begin{array}{l}\text { - Halal certification: new } \\
\text { application. } \\
\text { - Inspection area: kitchen, } \\
\text { storage room, dining, } \\
\text { dishes washing, processing } \\
\text { and preparation. }\end{array}$ \\
\hline \multicolumn{3}{|c|}{ Fourth Day: Kuala Lumpur } \\
\hline
\end{tabular}




\begin{tabular}{|l|l|l|}
\hline $\begin{array}{l}\text { Premise 7 } \\
\text { (chain } \\
\text { restaurant) }\end{array}$ & 1 hour, & $\begin{array}{l}\text { - Halal certification: add } \\
\text { menu and new application. } \\
\text { - Inspection area: pastry } \\
\text { products and cakes, dining. }\end{array}$ \\
\hline $\begin{array}{l}\text { Premise 8 } \\
\text { (food kiosk) }\end{array}$ & 10 minutes & $\begin{array}{l}\text { - Halal certification: new } \\
\text { application. } \\
\text { - Inspection area: storage, } \\
\text { containers, cabinets, } \\
\text { serving. }\end{array}$ \\
\hline $\begin{array}{l}\text { Premise 9 } \\
\text { (chain } \\
\text { restaurant) }\end{array}$ & 55 minutes & $\begin{array}{l}\text { - Halal certification: add } \\
\text { menu and new application. } \\
\text { - Inspection area: kitchen, } \\
\text { dining, food handling, } \\
\text { preparation, workers' } \\
\text { lockers, storage. }\end{array}$ \\
\hline $\begin{array}{l}\text { Premise 10 } \\
\text { (food kiosk) }\end{array}$ & 15 minutes & $\begin{array}{l}\text { Halal certification: add } \\
\text { menu and new application. } \\
\text { Inspection area: storage, } \\
\text { containers, cabinets, } \\
\text { serving. }\end{array}$ \\
\hline
\end{tabular}

The observation was carried out in four working days at various locations in Selangor and Kuala Lumpur, Malaysia. The observation was conducted with the collaboration of 14 Halal Auditor (Shariah and Technical experts or food technologist) from the Malaysia Halal Certification Body. During the inspection as well as the observation process, various areas in the food premises were observed mostly in the most critical sections. A 'checklist' was constructed and used to guide the researcher during the observations and notes were taken during the process. Then, the data collected is tabulated for further analysis.

\section{ANALYSIS AND RESULTS}

This section describes the analysis and results from the collected data.

\section{A. Interview Analysis}

In order to understand the research topics, thematic analysis has been conducted on the collected data, analysed and tabulated according to the identified theme. The classification of the information is categorized based on the Work System Framework [14].

From the interviews, the halal certification system and halal inspection process has been identified. After receiving an application and supporting documents from the applicant, Off-site Inspection is carried out by Halal Certification Body. If the necessary requirements are fulfilled, charge letter of service fee will be issued to the applicant before the preparation of Inspection Schedule where the auditor will be appointed. Each inspection team is consisting of two to five Shariah and Technical Halal Auditors. The number of Halal Auditors for each inspection team depends on the type and amount of food premises that need to be inspected. The application of halal certification will be ready for the On-site Inspection process when the Inspection Schedule is prepared.

At the applicant's food premise, the Halal Auditor starts with 'opening meeting' for a quick briefing of the inspection process. Then, they proceed with documents re-checking process to ensure the information declared in the online application system (or application form) is in line with the one documented and provided by the applicant at the inspection site. At this point, some Halal Auditor will also conduct the premise inspection simultaneously to save time. During this process, any evidence of non-compliance will be collected. Then, Halal Auditor will end the inspection process through a quick 'closing meeting' involving the inspection team and the applicant. The purpose is to discuss the findings which then will be documented and presented to the Halal Certification Panels for approval. If approved, Halal Certificate and Halal Logo will be awarded to the respective applicant.

Halal Auditor will use several documents and guidelines during the inspection process such as Halal Inspection checklist, halal certification manual procedure, the relevant food act and other supporting documents. They also inspection forms such as Halal Audit Report (HAR) and Non-Conformance Report (NCR) to record the evidence of non-compliance found during the inspection process.

In term of technological implementation, it is also identified that Halal Auditor is using numerous inspection tool, equipment and devices. This includes computers, tablets, smartphones, mobile navigational application (i.e. Google Maps, Waze Apps, etc.), digital camera, flashlight and stopwatch, sampling tools and apparatus. Some equipment will be used in certain specific situation for a special purpose such as to collect a sample for laboratory analysis; only if necessary.

\section{B. Observation Analysis}

From the observations, it is identified that each halal inspection process can be conducted as quick as 10 minutes only. However, the duration of the process is depending on the size and location of inspected premise. If the inspected food premise is never been examined due to the new application, longer inspection time is required to assess the food establishment carefully. Meanwhile, for the renewal or additional menu application, usually, the inspection process will be done much faster. In certain situation, the process can extend up to two hours to be completed. The readiness of the applicant for the halal inspection process and the size of the inspection team also influence the evaluation flow.

In term of the process implementation, halal inspection is conducted in the same way as discussed in 
the previous section. Halal Auditor will conduct the process based on the certification manual procedure as it begins and ends with opening and closing meeting respectively. The team leader begins the process with a quick briefing on the halal inspection at the opening meeting. Then, he or she will request the necessary supporting documents of halal certification. After that, they begin the premise inspection process where in certain cases, the inspection team is divided into subgroups. One for documents re-checking process and another is for premise inspection process. It is also observed that both processes are carried out simultaneously by the Halal Auditor in order to make the process faster. During premise inspection, all sections will be evaluated. Some sections which considered as "critical area' such as the preparation and processing area, cooking area, storage area, cold room, refrigerators, dining and serving area, and many more.

In this process, Halal Auditor will look for the evidence of non-compliance based on the Shariah and technical perspective. Any non-halal products such as alcohol products, risky element of contamination (i.e. rusty equipment, unclean storage, etc.), prohibited animals (pigs, dogs, or any parts of it) and the product with doubtful halal status must be identified. If necessary, samples of unwanted elements will be taken for further analysis. Pictures or sometimes video of evidence will also be taken. This process continues until they are satisfied with the inspection findings which then will be discuss between the inspection team for final evaluation. Finally, the halal inspection process ends with the closing meeting between the inspection team and the applicant or the person-in-charge at the premise. This is to discuss the inspection findings and inform the applicant if there is any action of improvement required.

The things that need to be considered during the inspection process is specified in the Halal Inspection Checklist used by the Halal Auditor. However, this checklist only provides basic criteria of the inspection. The flow of the process still depends on the auditors' skills and experience in handling the situation. From the observations, it is also identified that there are some areas at the premise that are inspected longer than the others. This indicates that the area is given higher priority and more critical than the others. This shows that area must be assessed carefully.

As the result, there are about eleven critical control point (CCP) of the halal inspection has been identified (Table IV). This is also a summarization of the component of the inspection process which must always be assessed carefully. The CCP includes the food storage; non-food storage; raw product; processed product; utensils and cooking equipment; refrigeration machineries; cleaning and sanitation equipment; appearance, attire and personal hygiene; operating practices; waste management and disposal; and finally, pest control.

TABLE IV HALAL INSPECTION CRITICAL CONTROL POINTS

\begin{tabular}{|c|c|}
\hline \multicolumn{2}{|r|}{ ritical Control Points (CCP) } \\
\hline \multicolumn{2}{|c|}{$\begin{array}{l}\text { CCP1 - Food storage: } \\
\text { - Evaluate storage for dry \& wet product. } \\
\text { - Suitable room/ storage temperature. } \\
\text { - Food containers are labelled and storage method: 'First In, } \\
\text { First Out' }\end{array}$} \\
\hline \multicolumn{2}{|c|}{$\begin{array}{l}\text { CCP2 - Non-food storage: } \\
\text { - Non-food product must be stored separately from food } \\
\text { product. }\end{array}$} \\
\hline \multicolumn{2}{|c|}{$\begin{array}{l}\text { CCP3 - Raw product: } \\
\text { - Valid halal certificate \& logo and certified by recognised Halal } \\
\text { certification body. } \\
\text { - Properly labelled according to the relevant guidelines \& } \\
\text { regulations. }\end{array}$} \\
\hline \multicolumn{2}{|c|}{$\begin{array}{l}\text { CCP4 - Processed product: } \\
\text { - Check finished product (i.e. ready-to-serve food, pastry and } \\
\text { cake product). }\end{array}$} \\
\hline & \multirow{3}{*}{$\begin{array}{l}\text { - Maintenance (keep equipment } \\
\text { in clean, good condition, \& place } \\
\text { in suitable area). } \\
\text { - Usage (use for halal product } \\
\text { only). } \\
\text { - Material (made of non- } \\
\text { hazardous element non-animal- } \\
\text { based product such as brushes } \\
\text { that made of animal hair are not } \\
\text { allowed). }\end{array}$} \\
\hline & \\
\hline & \\
\hline \multicolumn{2}{|c|}{$\begin{array}{l}\text { CCP8 - Appearance, attire \& personal hygiene: } \\
\text { - Practice code of ethics \& use suitable attire. } \\
\text { - Body hygiene and health must always be maintained. }\end{array}$} \\
\hline \multicolumn{2}{|c|}{$\begin{array}{l}\text { CCP9 - Operating practices: } \\
\text { - Handle, prepare and process food product properly. }\end{array}$} \\
\hline \multicolumn{2}{|c|}{$\begin{array}{l}\text { CCP10 - Waste management \& disposal: } \\
\text { - Cleaning schedule must be monitored. } \\
\text { - Have organised washing stations (washing, rinsing \& } \\
\text { sanitizing). }\end{array}$} \\
\hline & \\
\hline
\end{tabular}

In this research, the CCP of halal inspection as described in Table IV is illustrated as the component of the Halal Virtual Inspection Model (Fig. 4). It was designed based on the elements of the Work System Framework (WSF) [14] and organized according to the inspection process at the premise. 


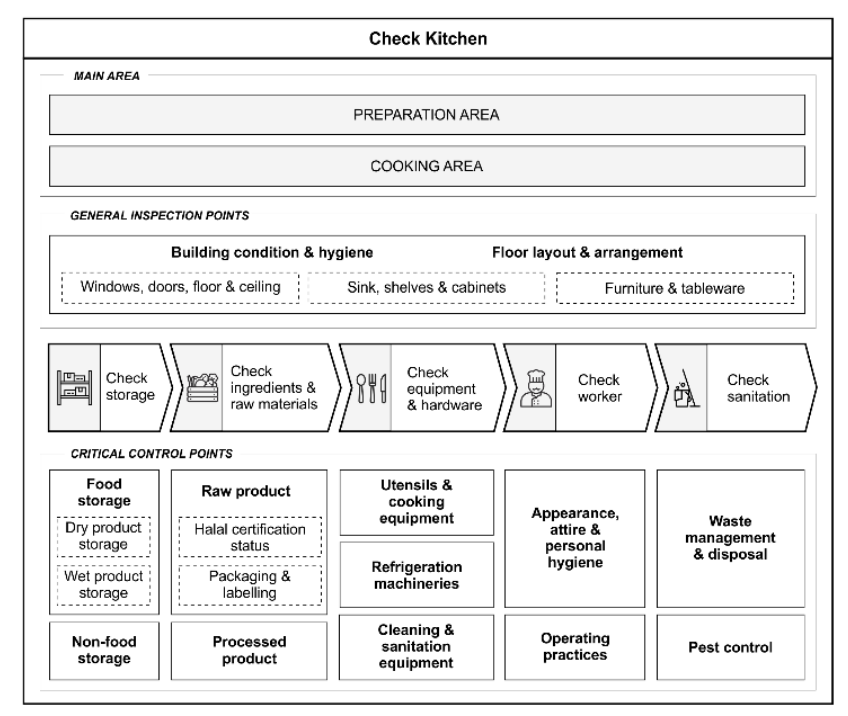

Fig. 4 Halal Virtual Inspection Model

\section{DISCUSSIONS}

The results have found some important findings. The first is related to the implementation of the halal certification system and halal inspection process. Halal certification has a rigorous evaluation procedure involving the technical and religious requirements, especially the halal inspection process. In term of its application, each halal inspection process must comply with the minimum requirement of which at least two Halal Auditors of the Shariah and technical experts (food technologist). They work together as a team to identify any evidence of non-compliance under the Shariah (Islamic law). In general, Halal Auditor is the expert Islamic religious matters and food technology, welltrained personnel and knows 'what' or 'which' critical point that needs to be examined during the inspection process. Furthermore, the auditor may have to interview the person-in-charge at the inspected premise to obtain the required information. On top of that, the criteria and the flow of the halal inspection process at different food establishment may have a different requirement. The larger premises require a more detailed assessment by the auditors.

The second important finding is on how halal certification plays its role as a Muslim-friendly quality assurance system. Although there is a lot of food safety and quality assurance systems that internationally recognized such as Good Manufacturing Practices (GMP), Good Hygiene Practices (GHP) and Hazard Analysis Critical Control Points (HACCP) (see Section II), Muslims community still requires the halal certification system to guarantee their foods, products or services are halal. This is because it involves the evaluation on everything from the technical and Islamic aspect. Therefore, as halal certification system holds such a crucial role, its implementation needs to perform effectively and efficiently.

The third finding is in term of the way of modern information and communication technology (ICT) such as virtual technology is vision to improve the existing halal inspection method. The virtual collaboration of the halal inspection team believe can improve the productivity of the system as it will eliminate many boundaries especially in term of the cost involved, the time required and its working environment. The Computer Supported Cooperative Work (CSCW) framework gives an outline of how such a visionary approach can be utilized to empower the existing halal certification system.

The fourth finding uncovered the essential part of this article which highlights the critical control points (CCP) of the inspection process. As previously discussed, the CCP is the imperative structure that must be put into attention in order to virtualize the process. Of course, not all components of the inspection process can be covered or virtualized at the current stage. Therefore, further studies are needed so that the true virtualization elements of the inspection process will be revealed.

\section{CONCLUSIONS}

In conclusion, this article provides a review on the halal certification system, halal inspection process and have highlighted several critical control points (CCP) of the inspection process. In this paper, the exploration is limited to only a small part of the inspection process (onsite halal inspection process for checking kitchen only). This is to narrow down the scope of the study. The CCP has been uncovered which described the critical component of the inspection process. For the virtualization of halal inspection, it may all or only some of the CCP are applied. However, further study regarding this matter is required to help halal certification practitioners in evaluating the CCP and identified it virtually but still comply with the halal requirements. Surely, there are some issues that will be encountered during the process. However, researcher believed such a problem can be reduced using modern technology such as virtual technology. This kind of technology has been applied in many areas but still limited in the halal certification field. Therefore, an in-depth research needs to be carried out further.

The Halal Virtual Inspection Model that proposed in this paper gives some guidance for the halal inspection process virtualization as its element highlights the crucial parts of the process. Information and communication technology (ICT) can be utilized in synchronous and/or asynchronous approach. Either way, the implementation of it must always comply with the relevant halal standards and requirements. Unfortunately, this 
research is limited to just the exploration of only a small part of the whole halal inspection process. The findings did not uncover a complete structure of the halal virtual inspection process and its element. Thus, it must be explored in the future.

\section{ACKNOWLEDGMENT}

This research is supported and funded by the Ministry of Higher Education Malaysia and Universiti Teknologi MARA, Malaysia under the grant RAGS/1/2015/ICT04/UITM/02/1. Our gratitude also goes to the Department of Islamic Development Malaysia (JAKIM), all the respondents, participants and other authorities for their support.

\section{REFERENCES}

[1] M. N. Mohamad and N. Othman, "Audit Pengesahan Halal - Kajian di Jabatan Kemajuan Islam Malaysia," J. Penyelid. Islam, vol. 22, pp. 19-54, 2009.

[2] J. E. See, "Visual Inspection: A Review of the Literature," New Mexico, 2012.

[3] J. Alzeer, U. Rieder, and K. A. Hadeed, "Rational and practical aspects of Halal and Tayyib in the context of food safety," Trends Food Sci. Technol., no. July, pp. 1-0, 2017.

[4] M. Saad, P. S. Toh, and M. A. M. Adil, "Hygiene practices of food handlers at Malaysian Government Institutions Training Centers," Procedia - Soc. Behav. Sci., vol. 85, pp. 118-127, 2013.

[5] A. N. Ahmad, U. F. Ungku Zainal Abidin, M. Othman, and R. Abdul Rahman, "Overview of the halal food control system in Malaysia," Food Control, vol. 90, pp. 352-363, 2018.

[6] Department of Islamic Development Malaysia [JAKIM], Manual Procedure for Malaysia Halal Certification (Third Revision) 2014, 3rd ed. Seri Kembangan, Selangor: Department of Islamic Development Malaysia (JAKIM), 2014.

[7] M. N. Demirci, J. M. Soon, and C. A. Wallace, "Positioning food safety in Halal assurance," Food Control, vol. 70, pp. 257-270, 2016.

[8] M. A. Abdul Majid, I. H. Zainal Abidin, H. A. Mohd Abd Majid, and C. Tamby Chik, "Issues of Halal Food Implementation in Malaysia," J. Appl. Environ. Biol. Sci., vol. 5, no. January, pp. 50-56, 2015.

[9] H. Elasrag, "Halal Industry: Key Challenges and Opportunities," Munich Pers. RePEc Arch., vol. 69631, no. January 13, 2016.

[10] R. Mohamed Ismail, "Global issues and challenges for the halal food industry," in China (Ningxia) International Cooperation Forum on Halal Food Certification, 2015, no. September, pp. 124133.

[11] N. Noordin, N. L. Md Noor, M. Hashim, and Z. Samicho, "Value Chain of Halal Certification System : A Case of The Malaysia Halal Industry," Eur. Mediterr. Conf. Inf. Syst. 2009, pp. 1-14, 2009.

[12] M. I. Illyas Tan, "a QuikHalal - A solution to Halal certification process for industry," UTM Research, 2017. [Online]. Available: http://www.utm.my/research/2017/10/05/quikhalal-a-solution-tohalal-certification-process-for-industry/. [Accessed: 31-Jan-2018].

[13] R. A. Holley, "Smarter inspection will improve food safety in Canada," CMAJ, vol. 182, no. 5, pp. 471-473, 2010.
[14] S. Alter, "Work System Theory: Overview of Core Concepts, Extensions, and Challenges for the Future," J. Assoc. Inf. Syst., vol. 14, no. 2, pp. 72-121, 2013.

[15] V. M. R. Penichet, I. Marin, J. A. Gallud, M. D. Lozano, and R. Tesoriero, "A Classification Method for CSCW Systems," Electron. Notes Theor. Comput. Sci., vol. 168, no. SPEC. ISS., pp. 237-247, 2007.

[16] G. D. Orriss and A. J. Whitehead, "Hazard analysis and critical control point (HACCP) as a part of an overall quality assurance system in international food trade," Food Control, vol. 11, pp. 345351, 2000.

[17] Intergovernmental Panel on Climate Change (IPCC), "Quality Assurance and Quality Control," 2012.

[18] A. Kujawińska and K. Vogt, "Human factors in visual quality control," Manag. Prod. Eng. Rev., vol. 6, no. 2, pp. 25-31, 2015

[19] G. Rotaru, N. Sava, D. Borda, and S. Stanciu, "Food Quality and Safety Management Systems: a Brief Analysis of the Individual and Integrated Approaches," Agroaliment. Process. Technol., vol. XI, no. 1, pp. 229-236, 2005.

[20] Department of Standards Malaysia, "Accreditation Certification Bodies (ACB) - Good Manufacturing Practice for Food (GMP)," no. 1, 2013.

[21] J. Nordenskjöld, "Implementation of a quality management system in food production," Swedish University of Agricultural Sciences, 2012.

[22] Ministry of Health Malaysia, Garis Panduan Amalan Kebersihan yang Baik [Good Hygiene Practice (GHP)] untuk Industri Makanan Skala Kecil dan Sederhana (IKS) ke Arah Perlaksanaan HACCP (Hazard Analysis Critical Control Point). 2002.

[23] P. A. Pawar and A. H. Purwar, "HACCP in Retail and Food Service Operations," Int. J. Eng. Sci. Invent., vol. 2, no. 10, pp. 50-66, 2013

[24] M. I. Khan and H. Abid, "Understanding "Halal' and "Hala Certification \& Accreditation System ' - A Brief Review," Saudi J. Bus. Manag. Stud., vol. 1, no. 1, pp. 32-42, 2016.

[25] M. Z. M. Sulaiman, N. Noordin, N. L. M. Noor, A. I. H. Suhaimi, and W. A. R. W. M. Isa, "Halal Inspection Process at Federal and State Level : A Case Study of Halal Certification System in Malaysia," in 2017 IEEE Conference on Open Systems (ICOS), 2017, pp. 65-70.

[26] N. Noordin, "Efficiency Factors and Ecosystem Framework in Malaysian Halal Food Certification System," Universiti Teknolog MARA, 2013.

[27] M. A. Ali Farooqui and N. Kurt, "Inspection Procedures in Halal Food Certification," al-Adwa, vol. 39, no. 28, pp. 17-32, 2005.

[28] L. Ab. Rahman, "Shariah \& Malaysian Halal Certification System," J. Penyelid. Islam, vol. 18, pp. 15-36, 2005.

[29] M. Z. M. Sulaiman, N. Noordin, N. L. M. Noor, A. I. H. Suhaimi, and W. A. R. W. M. Isa, "A preliminary study of halal virtual inspection: A case of halal certification in Malaysia," in Proceedings - 6th International Conference on Information and Communication Technology for the Muslim World, ICT4M 2016, 2016, pp. 93-98.

[30] N. Bolloju, S. Alter, and S. Francisco, "Better Use Case Diagrams by Using Work System Snapshots," vol. 9, no. 2, pp. 1-22, 2016.

[31] M. Mrázik, "Computer Supported Cooperative Work," Comenius University, Bratislava, Slovakia, 2007.

[32] A. Mørch, "Introduction to CSCW and Groupware," InterMedia. University of Oslo, pp. 1-24, 2009. 